\title{
The Road to Modern Judiciary. Why New Technologies Can Modernise the Administration of Justice?
}

\author{
Mariusz Zatucki<mzalucki@afm.edu.pl> \\ KRAKÓW, Poland
}

\section{Abstract}

The future of administration of justice is an issue increasingly often discussed in the literature. Representatives of the doctrine wonder about the greater use of new technologies in the judiciary, so as to, among other things, shorten the waiting time for a case to be decided by the court. Changes taking into account the wider use of new technologies are indispensable. Such a future has already been foreseen in the literature. The author reviews selected reported and functioning ideas, presents how the judicial field has changed recently and reflects on possible future solutions. The result of his observations is a conclusion about the need to discuss the future of justice on a broad, global scale.

Keywords:

Judiciary, justice, administration of justice, courts, new technologies, AI

\section{Introduction}

Today's judiciary is a complex structure, with specialised courts and judges, although there is no consensus in individual states on how judicial power should be exercised. It is the political system of a given state, regulated by acts of the highest rank, usually in the form of a constitution, which defines the subject of state authority, including judicial authority, delineates its scope and indicates the main directions of state activity. According to the traditional division, derived from ancient thought developed by Enlightenment thinkers, the judiciary is one of the authorities, independent from the executive and legislative powers. ${ }^{1}$ The position of

1 Mehrdad Payandeh, Judikative Rechtserzeugung: Theorie, Dogmatik und Methodik der Wirkungen von Präjudizien (Mohr Siebeck 2017) $2 \mathrm{ff.}$ 
the judiciary in the system of a tri-partition of powers is largely based on the isolation of the judicial power, the competence monopoly of the judiciary in the exercise of that power, one of the basic tasks of which is to administer justice. ${ }^{2}$ The organs of the judiciary are to resolve disputes arising in connection with the application or making of law, they decide on citizens' rights and obligations. One of the basic elements of a legal state is the citizen's access to court, the existence of a judicial sphere for resolving disputes. ${ }^{3}$

The judiciary, in the course of several centuries of evolution, has developed a specific model of the organisation of the judiciary, which is now reflected primarily in the provisions of fundamental laws, as well as in legal regulations of a lower order defining the system of the judiciary in a given state. For the courts to function properly within the system of state bodies, it is necessary to ensure respect for and observance of the independence of the judiciary, which is, inter alia, the duty of state bodies. Of great importance for assessing the proper functioning of courts is the access of citizens to a court, understood primarily as the right to have a case heard within a reasonable time by an independent and impartial court. Interestingly, according to the OECD, is that only $46 \%$ of people live in conditions which can be said to be subject to such legal protection, while, for example, over $50 \%$ of all people today have access to the Internet. ${ }^{4}$ Access to the court is therefore more limited than access to the Internet, which may raise and raises important questions.

One of the greatest problems of the justice system, related to the access of citizens to the court, is the lengthiness or even protraction of examination of individual cases. ${ }^{5}$ Legal regulations on the protection of human rights, including e.g. the European Convention on Human Rights, have for a long time created a standard for the so-called fair trial (Article 6 ECHR), which consists, inter alia, of the right to a fair and public hearing within a reasonable time. ${ }^{6}$ However, individual countries of the world

2 Lech Garlicki, Polskie prawo konstytucyjne. Zarys wyktadu (Wolters Kluwer Polska 2020) $75 \mathrm{ff}$.

3 Cf. Paul Craig and others, Rule of Law in Europe Perspectives From Practitioners and Academics (European Judicial Training Network 2020) $43 \mathrm{ff}$.

4 Cf. Richard Susskind, Online Courts and the Future of Justice (Oxford University Press 2019) 27.

5 José María López Jiménez, ‘Sistemas Judiciales Justos Y... Eficientes’ (2013) 2013 eXtoikos 31.

6 William A Schabas, The European Convention on Human Rights: A Commentary (Oxford University Press 2015) $264 \mathrm{ff}$. 
have problems with the implementation of this standard, as evidenced, for example, by the various legal remedies brought against these countries for violation of this standard, including, inter alia, complaints to the European Court of Human Rights about the so-called lengthiness of judicial proceedings. ${ }^{7}$ As one may think, and as the available data show, also the recent period of functioning of the justice system in the era of the COVID-19 pandemic has revealed a number of difficulties related to adjudication of court cases within a reasonable time. ${ }^{8}$ However, social expectations in this respect are significant. Basically, everyone would like their case to be heard quickly.

In this light, it should be noted that lawyers all over the world are considering improvements to the functioning of the judiciary. Recent years have seen an increasingly bold use of solutions based on new technologies, which can be categorised as LegalTech 1.0, 2.0 and 3.0.9 Courts have started to operate on the Internet, algorithms have appeared to support their work, and even solutions based on artificial intelligence have appeared, which in some categories of cases make it possible to replace a traditional judge. ${ }^{10}$ All these solutions were and undoubtedly are intended to improve the efficiency of the justice system. Looking at some of these solutions, it is necessary to reflect on the further possible direction of changes in judicial proceedings, using new technologies, so that, while respecting the standards in force in this area, the functioning of the courts is modernised and improved. What can and should the courts of the future be like?

\section{The current state and recent developments in the judiciary}

The issue of lengthiness or protraction of proceedings is widely commented upon in the doctrine and judicature. ${ }^{11}$ It is not only of theoretical importance. First of all, it is a practical problem. Lengthiness of proceedings, which can be understood as violation of a party's guarantee to have its

7 Schabas (n 6).

8 David Freeman Engstrom, 'Post COVID Courts' (2020) 68 UCLA Law Review Discourse 246, $249 \mathrm{ff}$.

9 Cf. Dariusz Szostek (ed) LegalTech. Czyli jak bezpiecznie korzystać z narzędzi informatycznych $w$ organizacji, $w$ tym $w$ kancelarii oraz dziale prawnym (C H Beck 2021) passim.

10 Cf. Paulo Cezar Neves Junior, Judiciário 5.0. Inovação, Governança, Usucentrismo, Sustentabilidade e Segurança Jurídica (Edgard Blücher 2020) passim.

11 Susskind (n 4). 
case heard within a reasonable time, is a problem of many countries. ${ }^{12}$ The pursuit of efficient and speedy examination of a case cannot be an aim in itself. Nevertheless, inefficiency is undoubtedly one of the key factors disrupting the proper functioning of the justice system and hampering the assertion and protection of rights. The negative consequences of lengthy court proceedings are evident. For example, in civil cases, lengthiness not only undermines the sense of justice actually being done, but can also result in the merely illusory nature of the legal protection provided. For example, there may be a loss of value resulting from the devaluation of money in payment cases, or the debtor losing property to which enforcement can be directed, or its value decreasing. In cases for the surrender of property, the loss of its usefulness associated with the passage of time and technological progress may occur, another example is the inability of entities, the resolutions of which have been challenged (e.g. companies) to function properly. ${ }^{13}$ Generally speaking, it may be pointed out that with the passage of time, a decision may lose its significance for the parties due to changes in the socio-economic reality or technological progress. ${ }^{14}$ It is therefore obvious that the lengthiness of court proceedings is an undesirable state of affairs, and that a court proceeding lasting as short as possible is optimal.

The efficiency of the justice system is stimulated at various levels, although the effect of the various measures stimulating the judiciary is not always correct. ${ }^{15}$ It should be remembered that when resolving cases, speed of proceedings should not overshadow other procedural guarantees of the parties. ${ }^{16}$ This can be seen against the background of modern legal systems, where the right to a court and the right to a fair trial (and thus the requirement of a speedy resolution of the case) are constitutional principles of a democratic state under the rule of law, being protected under the constitution. For example, the Polish Constitution in the content of Article 45 par. 1 indicates that everyone has the right to a fair and public hearing without undue delay by a competent, independent and impartial

12 Szymon Rożek, Sprawność sądowego postępowania cywilnego na tle rozstrzygania spraw spadkowych (Krakowska Akademia 2020).

13 ibid.

14 ibid.

15 Richard Susskind, Tommorow's Lawyers. An Introduction to Your Future (Oxford University Press 2017).

16 Janneke Gerards, General Principles of the European Convention on Human Rights (Cambridge University Press 2019); Amal Clooney and Philippa Webb, The Right to a Fair Trial in International Law (Oxford University Press 2021). 
court. ${ }^{17}$ This striving for the absence of delay in the examination of cases is noticeable in the mechanisms available to the parties and related to combating protraction. In this context, the already mentioned Polish law, as early as in $2004,{ }^{18}$ following the case-law of the ECHR, ${ }^{19}$ introduced the mechanism of a complaint against the lengthiness of court proceedings, which consists in bringing a complaint to a court superior to the court before which the proceedings are pending, in which the court may declare that in the proceedings to which the complaint relates, there has been a lengthiness of proceedings. The court may, inter alia, at the request of the party or of its own motion, order the court with jurisdiction over the substance of the case to take appropriate action within a specified period of time, but such directions shall not extend to the factual and legal assessment of the case. The court may also award the applicant an appropriate sum of money. However, this mechanism has not resulted in any significant decrease in the length of court proceedings. Current media reports and available data indicate that the average length of court proceedings has increased by around 3 months from 2010 to $2020 .{ }^{20}$ Currently, selected categories of cases are heard in first instance on average after approximately 7 months. ${ }^{21}$ Waiting times have therefore increased by $75 \%$. Statistics of this kind are not unknown in other countries either. ${ }^{22}$ The increase in the number of cases, their increasingly complex subject matter, the growing number of legal regulations, their complexity, etc., all lead to an impaired functioning of the judiciary. Court cases are taking longer and longer to be heard.

This must therefore mean that the threat to the efficiency of judicial proceedings is increasing. In the era of the COVID-19 pandemic, when the courts were not working for a period of time, adjusting to the demands of social isolation, the waiting period for a party to have the case heard continued to increase. ${ }^{23}$ The justice system did not function for some time, or only heard urgent cases, including those related to crime or family pro-

17 Garlicki (n 2).

18 This is when the Act of 17 June 2004 on Action for Infringement of a Party's Right to Judicial Proceedings without Undue Delay was enacted.

19 The introduction of the complaint to the Polish legal order is commonly associated with the implementation of the ECHR judgment of 26.10.2000 in the case of Kudła v. Poland, case No. 30210/96.

20 Cf. Report of the Ministry of Justice: Średni czas trwania postępowania sądowego w latach 2011-2020, <https://isws.ms.gov.pl/pl/baza-statystyczna/opracowania-wiel oletnie> accessed 23 June 2021.

21 ibid.

22 Jiménez (n 5).

23 Engstrom (n 8). 
blems, especially involving minor children. Traditional civil cases, especially those with a high number of small claims, were not heard. Lawyers all over the world thought about modifying court procedures and prepared solutions that would make it possible and, to a large extent, unblocked the resulting bottlenecks. ${ }^{24}$ The judicial process has changed, certain simplifications have been introduced into the procedures, including, among others, the large-scale use of means of distance communication. Hearings went online, judges started using IT solutions that had been available for years to question witnesses and parties. ${ }^{25}$ Although this was supposed to be a temporary solution, it is already clear that the old analogue instruments will be and are being replaced by instruments based on new technologies.

Judicial procedures have changed. ${ }^{26}$ Before the pandemic, many countries had a model according to which the party and witnesses, as well as other persons important for the examination of the case, met in the court building, in the courtroom, where the case was examined. The obligation of social isolation forced the search for other solutions. It soon turned out that a different course of the trial was possible and that the parties and other persons did not have to stay in the same building to have the case heard. These solutions were becoming more and more daring, which, among other things, led to the tendency to hear cases in closed sessions. As a rule, a regulation was introduced, according to which, where the court deems it sufficient, it passes a sentence without the presence of the parties. The possibility for third parties (the public) to participate in a court hearing and observe its proceedings has also been significantly restricted or completely eliminated. ${ }^{27}$ Meanwhile, openness of proceedings is also, at least according to current standards, one of the basic values taken into account when assessing whether the standard of the so-called fair trial was observed in a given case. The law and values may therefore change under the influence of various impulses. And there is no doubt that they are changing.

As is well known, some countries have gone further. ${ }^{28}$ The need for the use of new technologies in the field of justice has long been discussed, and

24 ibid.

25 Szostek (n 9).

26 Mlle Andreea Mirela Staicu, La réforme du système judiciaire roumain dans le processus d' adhésion de la Roumanie à l' Union européenne Mémoire présenté par (ENA, 2006).

27 Such a future has already been foreseen in the literaturę, cf., e.g.: Susskind (n 4).

28 AD Dor Realing, 'Courts and Artificial Intelligence' (2020) 11 International Journal for Court Administration 1. 
following the tests made of some technological solutions in the judiciary, it is going even further. ${ }^{29}$ Here, as is also well known, the impetus for basing the judiciary on new technologies came from, among other things, two high-profile incidents around the world involving the use of artificial intelligence. In 2016, 584 cases pending before the European Court of $\mathrm{Hu}-$ man Rights were subjected to an experiment involving artificial intelligence. ${ }^{30}$ The algorithm, after analysing the case documents, predicted $79 \%$ of the decisions of this court. These settlements concerned claims under Article 3 (prohibition of torture, inhuman and degrading treatment), Article 6 (right to a fair trial) and Article 8 (right to respect for private and family life) of the European Convention on Human Rights. ${ }^{31}$ In turn, in 2017, a similar test was conducted in the United States of America, among others. $^{32}$ There, in turn, artificial intelligence analysed, on the basis of a created algorithm, more than 28 thousand cases pending before the Supreme Court there. The algorithm was able to predict $70.2 \%$ of cases decided between 1816 and $2015 .^{33}$ At the same time, the spectrum of cases was much broader than in the case of the test concerning the application of the standards of the European Convention on Human Rights in specific cases. Therefore, it is not surprising that the results of these experiments were widely echoed in the scientific space. ${ }^{34}$

It is worth explaining that the above tests were based primarily on the method of natural language processing, where the predictive model of artificial intelligence operating on text data was used. ${ }^{35}$ Extensive amounts of data were analysed to accurately predict the actual outcome. The results of the tests are interesting in that a large proportion of the errors in the

29 Mariusz Załucki, 'AI and dispute resolution' in Javier García González, Álvaro Alzina Lozano and Gabriel Martín Rodríguez (eds) El derecho público y privado ante las nuevas technologías (Dykinson 2020).

30 Nikolaos Aletras and others, 'Predicting Judicial Decisions of the European Court of Human Rights: A Natural Language Processing Perspective' (2016) 19 PeerJ Computer Science 93, $93 \mathrm{ff}$.

31 Masha Medvedeva, Michel Vols and Martijn Wieling, 'Using Machine Learning to Predict Decisions of the European Court of Human Rights' (2020) 28 Artificial Intelligence and Law 237.

32 Daniel Martin Katz, Michael J Bommarito II and Josh Blackman, 'A General Approach for Predicting the Behavior of the Supreme Court of the United States' (2017) 12 Plos One passim.

33 Katz, Bommarito II and Blackman (n 32).

34 Cf., e.g.: Haoxi Zhong and others, 'Legal Judgment Prediction via Topological Learning' (2018) 1 Proceedings of the 2018 Conference on Empirical Methods in Natural Language Processing; Realing (n 28).

35 Cf. Aletras and others (n 30). 
predictions related to similar legal standards, where only nuances in the jurisprudence determined a different outcome in reality. It should therefore be noted that a system dealing with the automation of the analysis, understanding, translation and generation of natural language by a computer in the context of the processing of specific decisions made in reality may be an interesting starting point for further research. ${ }^{36}$ Certainly, such experiments open up the controversial debate as to whether the traditional judge can be replaced by a computer. ${ }^{37}$ In this context, it should be noted that such views appear more and more frequently and boldly in scientific discourse, where, among other things, theses are formulated according to which, at least in some categories of cases, it seems possible. ${ }^{38}$

Such tests show that artificial intelligence, sometimes referred to as LegalTech 3.0, may be an interesting tool to assist in the administration of justice, and may one day be able to replace "real" judges. It is against this background that a number of possibilities, and at the same time doubts, arise. Are new technologies the future of justice?

\section{Selected solutions from around the world}

The above experiences with predictive systems show that changes in the administration of justice are possible. ${ }^{39}$ New technologies have already taken over the justice system. Just as in the past simple solutions were used in this area (the so-called LegalTech 1.0), ${ }^{40}$ today nobody can imagine further work in the judiciary without extensive legal information systems containing not only provisions of law, but also case law, commentaries and broad statements of doctrine and other instruments supporting the work of judges (the so-called LegalTech 2.0). ${ }^{41}$ All this, in the form of relevant data systematised in an appropriate way, is an important tool supporting

36 Cf. Study on the Use of Innovative Technologies in the Justice Field. Final Report (European Commission 2020).

37 Paul Bennett Marrow, Mansi Karol and Steven Kuyan, 'Artificial Intelligence and Arbitration: The Computer as an Arbitrator — Are We There Yet?' (2020) 74 Dispute Resolution Journal 35.

38 Załucki (n 29).

39 Mark Mckamey, 'Legal Technology: Artificial Intelligence and the Future of Law Practice' (2017) 22 Appeal: Review of Current Law and Law Reform 45.

40 Szostek (n 9).

41 ibid. 
the judiciary. ${ }^{42}$ This trend will continue, especially as it is predicted that around 2050 the development of technology will mean that the average computer will have a greater capacity to process data than the combined brains of all the inhabitants of the earth. ${ }^{43}$ It is therefore certain that the transfer of information resources to the digital world will continue, slowly replacing the use of traditional tools.

This trend has recently been visible, among others, in the context of communication with the courts. This is because it is increasingly bold to move to the virtual world. Individual legal systems are slowly abandoning traditional delivery of court correspondence and electronic delivery is appearing, which will slowly replace traditional court letters. ${ }^{44}$ An example of such a trend is that which can be observed, inter alia, in China, where a new system of communication with the courts is taking its first steps. Adoption of the Rules on the Provision of Online Case Service for Parties to Cross-border Litigation on 3 February $2021^{45}$ has changed the image of communication with courts. These Rules require Chinese courts to provide services that include guidance on initiating online cases, responding to enquiries, providing testimony via video, and initiating cases for parties in cross-border litigation. This is certainly the path that other countries will follow. Surely this is also a path from which there is no turning back.

China, however, has more to boast about in this regard. As of today, the country already has three internet courts that operate in Hangzhou, Beijing and Guangzhou, ${ }^{46}$ in which the settlement of cases is based, among others, on algorithms using artificial intelligence, or where the "Shanghai Intelligent Assistive case-handling system for criminal cases - System 206" operates, which is useful for solving criminal cases. ${ }^{47}$ The use of IT tools in the judiciary, with minimal human intervention, is already a standard. But is it possible to go even further in the transformation of the judiciary and, for example, replace the human being?

42 Cf., e.g.:Konrad Zacharzewski and Mariusz Tomasz Kłoda, Przeglą zastosowania technologii blockchain w wymiarze sprawiedliwości w wybranych państwach (Instytut Wymiaru Sprawiedliwości 2019).

43 Ray Kurzweill, The Singularity Is Near: When Humans Transcend Biology (Viking Press 2005).

44 Michał Araszkiewicz and Victor Rodriguez-Doncel (eds), Legal Konwledge and Information Systems (IOS Press 2019) passim.

45 (关于为跨境诉讼当事人提供网上立案服务的若干规定).

46 Changqing Shi, Tania Sourdin and Bin Li, 'The Smart Court - A New Pathway to Justice in China?' (2021) 12 International Journal for Court Administration 4.

47 Yadong Cui, Shanghai Intelligent Assistive Case-Handling System for Criminal Cases System 206 (Springer 2020) $43 \mathrm{ff}$. 
Interesting solution is being tested in the Netherlands, where a court in collaboration with research units is investigating the possibilities of artificial intelligence in the context of traffic offence cases in which a citizen appeals (contesting the validity of the penalties imposed for the offence). ${ }^{48}$ The aim of this work is to develop an artificial intelligence mechanism that would resolve such cases autonomously. ${ }^{49}$ Putting this tool into practice would mean the need for a serious rethinking of the judicial system. Such a task, one would think, has already been done in Estonia, for example. In this country, the first steps are being taken by a mechanism that assists judges by collecting certain data necessary to decide a case and analysing it in order to decide the case in the most equitable manner..$^{50}$ This mechanism is intended, among other things, as a response to the courts' inability to cope with the growing number of cases, so one of the motivations for working on this solution is the desire to improve the efficiency and effectiveness of case resolution. Its first task is to resolve the so-called minor cases, where the value of the subject of a dispute does not exceed the amount of 7000 EUR. Traditional judges are not involved in these settlements. The system is based on the parties providing documents supporting their positions, which are analysed by an algorithm which then issues the decision. Only an appeal against this decision is heard in the traditional way. This is certainly another step towards taking seriously solutions of this kind based on artificial intelligence, where the involvement of a human judge is minor (minimised). ${ }^{51}$ Thus, while traditional case disposal has its values, reaching for modern solutions based on artificial intelligence and other technologies also seems to be a direction from which there is and will be no turning back.

This technological future for the judiciary will undoubtedly present new challenges for legislators. ${ }^{52}$ These challenges, however, should not be feared, but rather, based on existing solutions, develop further possibilities

48 Manuella van der Put, 'Kan artificiële intelligentie de rechtspraak betoveren' (2019) 2 Rechtstreeks 50, $50 \mathrm{ff}$.

49 Put (n 48).

50 Franciska Z. Gyuranecz, Bernadett Krausz and Dorottya Papp, 'The AI Is Now in Session. The Impact of Digitalization on Courts' (European Judicial Training Network 2019) $8 \mathrm{ff}$.

51 Tanel Kerikmäe and Evelin Pärn-Lee, 'Legal Dilemmas of Estonian Artificial Intelligence Strategy: In between of e-Society and Global Race' (2020) 36 AI \& Society $561 \mathrm{ff}$.

52 David Freeman Engstrom and Jonah B Gelbach, 'Legal Tech, Civil Procedure, and the Future of American Adversarialism' (2020) 169 University of Pennsylvania Law Review 1. 
of technologies that will certainly appear. Here, for example, the solutions planned in Poland to be used in arbitration appear to be very interesting. The arbitration court operating at the Polish Notaries' Association in Warsaw already conducts completely electronic proceedings, and its IT system is largely automated, verging on AI mechanisms. ${ }^{53}$ In the future, it is planned to conduct analysis of case documentation and their assignment to specific legal norms by artificial intelligence, which is to be advisory and prepare draft awards with justifications. The system is also to support the arbitrator during the proceedings by providing him with information on the course and outcome of other similar cases. It is also supposed to present excerpts from the justifications of other judgments, which best explain a particular problem or legal issue. The announcements related to this are therefore promising. ${ }^{54}$ In this context, one wonders whether common courts could not also follow this path? The above-mentioned mechanisms, both those already operating in China or Estonia and those planned e.g. in Poland, would certainly make it possible to finally deal with the greatest problem of the judiciary of our times - the lengthiness of court proceedings. As one may think, this is an interesting avenue to pursue. New technologies can and should modernise the administration of justice. $^{55}$

\section{Towards the modernisation of the judiciary (instead of a conclusion)}

Consequently, as one may think, a judge, the judiciary, and the administration of justice are concepts that require redefinition and a modern outlook through the prism of the possibilities and effectiveness of new technologies. ${ }^{56}$ The justice system is confronted with a number of ills, and the most important one in recent times, the protraction or lengthiness of individual court proceedings, is an area where solutions are already visible. The Internet as a channel of communication, algorithms as tools supporting and sometimes replacing the traditional judge, is already a model that marks a

53 Cf. <https://ultimaratio.pl/sztuczna-inteligencja-w-ultima-ratio-czy-roboty-zastapia -arbitrow $>$ accessed 23 June 2021.

54 Tania Sourdin and Archie Zariski (eds), The Responsive Judge: International Perspectives (Springer 2018) passim.

55 Riikka Koulu and Laura Kontiainen (eds) How Will AI Shape the Future of Law? (University of Helsinki Legal Tech Lab publications 2019) passim.

56 Cf. Martin Ebers and Susana Navas (eds) Algorithms and Law (Cambridge University Press 2020); Susskind (n 15). 
new history for the judiciary. ${ }^{57}$ Relying on new technologies can be, and in an increasing number of cases already is, a solution thanks to which the time required to resolve a case is shorter. It therefore seems that individual legislators will follow this path and build their solutions on modern technologies. Modernisation of the justice system in this direction is essential. ${ }^{58}$ Those opinion groups and those discussants taking part in the discussion on the future of justice who advocate such a necessity, however, at the same time see a number of new challenges that technological changes in the administration of justice may bring about. After all, there is no doubt that part of the world, as has already been mentioned, does not use IT tools, is digitally absent (as I pointed out $50 \%$ of people in the world do not have access to the Internet). Modernisation of justice in this direction must not become a problem for this social group. What is needed, therefore, are intermediate, transitional mechanisms that guarantee not only efficiency and speed, but also the other elements that make up the so-called right to a fair trial. A fair trial is only fair if the case of an individual is heard within a reasonable time by an independent and autonomous court, taking into account existing standards of the rule of law. ${ }^{59}$ These standards will have to evolve, and the main challenge for them, which can already be foreseen today, will be to reconcile the role of the traditional judge with the automated world of administering justice. The possibility of a human judge being replaced by a computer is not a "naive euphoria" 60 but a future reality. It is therefore not only possible to envisage various technological solutions supporting judicial activities and performing judicial activities in this way, but also the further development of courts, especially online courts (which could be called second-generation courts in the modern judiciary), where the tasks of the judge will be performed in a virtual environment by machines, based on functioning algorithms.

Applications, smartphones, portals, chat bots, livechats, webcasts - all these tools can help non lawyers to interact with the court, and the court itself will also rely on technology. Justice 2050 will reflect technological trends. The use of artificial intelligence and other technologies in the

57 Judit Glavanits and Péter Bálint (eds) Law 4.0 - Challenges of the Digital Age (Széchenyi István University 2019).

58 Cf. Report: Possible Introduction of a Mechanism for Certifying Artificial Intelligence Tools and Services in the Sphere of Justice and the Judiciary: Feasibility Study (European Comission 2020).

59 Schabas (n 6) $264 \mathrm{ff}$.

60 As indicated by Aneta M Arkuszewska, Informatyzacja postępowania arbitrażowego (Wolters Kluwer 2019) $39 \mathrm{ff}$. 
judiciary on a wider scale is only a matter of time. Today is the time for a wider global discussion on these standards. The courts of the future should make use of new technologies; legislators must make this possible. 
